\title{
Could rare amino acids regulate enzymes abundance?
}

Valentina Agoni

valentina.agoni@unipv.it

University of Pavia - Italy

The number of every enzyme is the result of many mechanisms of regulation, at transcriptional and translational levels. We asked if the presence of rare amino acids in the sequence of an enzyme could represent a limiting factor in the balance between enzymes synthesis and enzymes efficiency. To try to find a correlation we analyzed the amino acids sequences of different housekeeping and metabolic enzymes.

Like in economical model of pricing there is an equilibrium point between marginal cost and marginal revenue curves in the quantity vs price plot, similarly these concepts can be applied to enzymes synthesis and its energetic cost.

The number of copies of a certain enzyme is the result of many mechanisms of translational, transcriptional and post-translational modification regulation.

Gene expression can be regulated at several different levels, for example (1-17):

- Initiation of transcription by repressor or activator proteins

- Premature termination of transcription by attenuation

- Initiation of translation by an antisense RNA

- Chromatin domains

- Modification of DNA

- RNA transport

- mRNA degradation

- Post-translational by proteolysis or modification of the gene product 
The frequency of the different amino acids in proteins (Figure 1) is known and these frequencies essentially reflect their frequency in nature and food, with the exception of arginine (18-20).

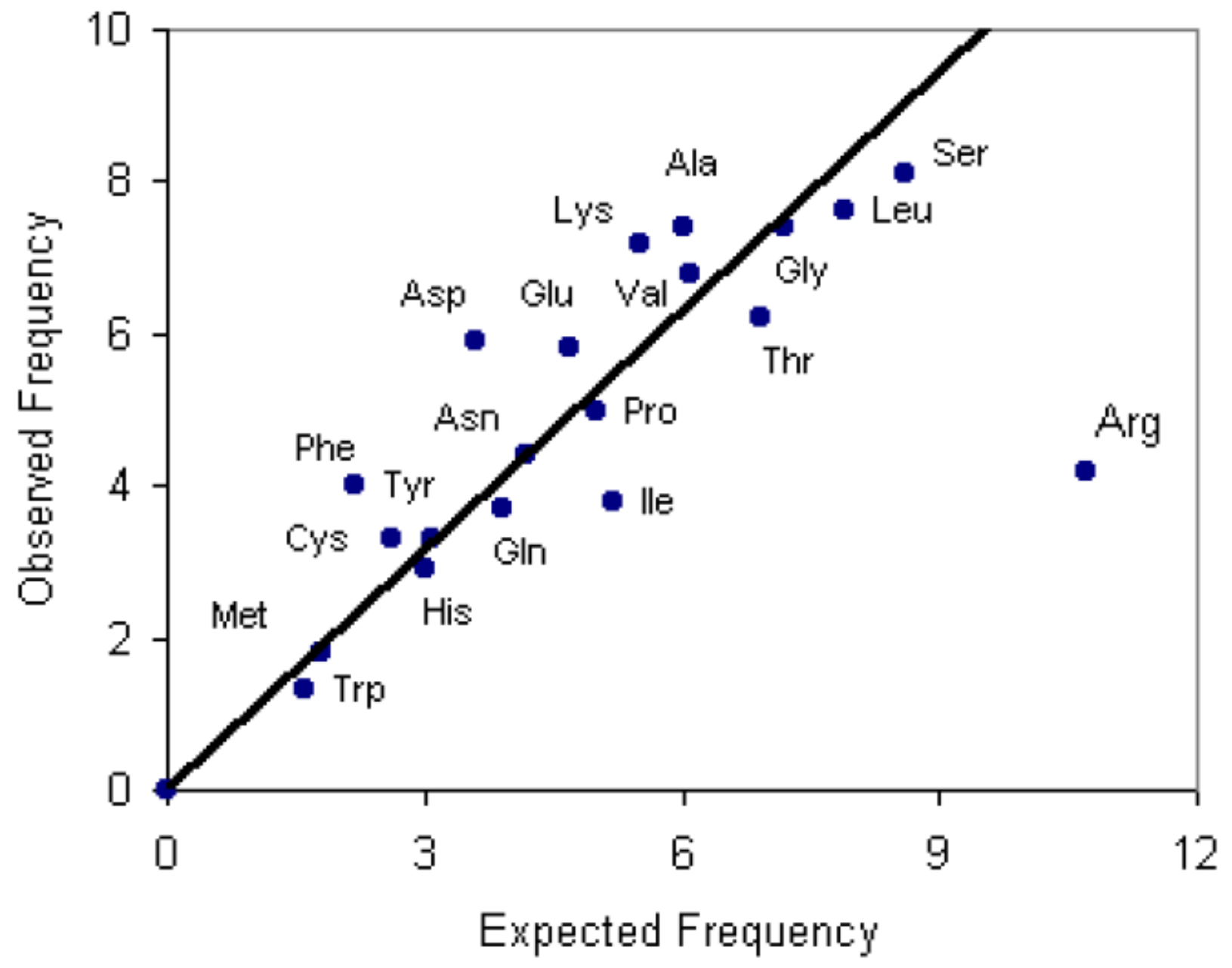

Figure 1. Amino acids expected frequency against the observed frequency in proteins (http://www.tiem.utk.edu/ gross/bioed/webmodules/aminoacid.htm).

Essential amino acids in humans are:

Phe Val Thr Trp Met Leu lle Lys His and they correspond to the less used in protein sequences. 
The amino acids frequencies are related to the proportion of alpha-helices and betastrands in a protein.

In particular the amino acids more prone to create of alpha-helices are:

Met Ala Leu Glu Lys

While the more abundant in beta-strands are:

Tyr Phe Trp Thr Val lle

We hypothesize that the frequency of each amino acid in proteins could represent a mechanism of regulation of enzymes relative abundance.

Here we consider the rarer and the more abundant amino acids: Trp (W) and Ser (S) respectively in housekeeping (h.k.) and metabolic or other enzymes.

H.k. enzymes vary their number of very little amount while the abundance of other enzymes can be much more variable reflecting physiological conditions (21-22).

According to our hypothesis the frequency of rare amino acids in h.k. enzymes should be higher respect to other enzymes.

For example Trp - the rarer amino acid in proteins- number should be lower in citrate synthase respect to GAPDH (glyceraldehyde-3-phosphate dehydrogenase).

However we can claim that there are no evidences of this correlation.

The results are reported in the attachment of this article.

In other words, at least in principle, there is no relation between amino acids frequencies and the regulation of enzymes number. 


\section{Bibliography}

1. Pereira, S. L.; Rodrigues, A. S.; Sousa, M. I.; Correia, M.; Perestrelo, T.; RamalhoSantos, J. (2014). "From gametogenesis and stem cells to cancer: common metabolic themes". Human Reproduction Update 20 (6): 943.doi:10.1093/humupd/dmu034. ISSN 1355-4786.

2. Bell JT, Pai AA, Pickrell JK, Gaffney DJ, Pique-Regi R, Degner JF, Gilad Y, Pritchard JK (2011). "DNA methylation patterns associate with genetic and gene expression variation in HapMap cell lines". Genome Biology 12 (1): R10. doi:10.1186/gb-201112-1-r10. PMC 3091299. PMID 21251332. edit

3. Vertino PM, Spillare EA, Harris CC, Baylin SB (April 1993). "Altered chromosomal methylation patterns accompany oncogene-induced transformation of human bronchial epithelial cells" (PDF). Cancer Res. 53 (7): 1684-9. PMID 8453642.

4. Austin S, Dixon R (June 1992). "The prokaryotic enhancer binding protein NTRC has an ATPase activity which is phosphorylation and DNA dependent". EMBO J. 11 (6): 2219-28. PMC 556689. PMID 1534752.

5. Barnett, J. A. (2004), A history of research on yeasts 7: enzymic adaptation and regulation. Yeast, 21: 703-746. doi: 10.1002/yea.1113

6. Dequéant ML, Pourquié $\mathrm{O}$. Segmental patterning of the vertebrate embryonic axis. Nat Rev Genet. 2008 May;9(5):370-82.PMID 18414404

7. Gilbert SF (2003). Developmental biology, 7th ed., Sunderland, Mass: Sinauer Associates, 65-6. ISBN 0-87893-258-5.

8. PMCID: PMC453065

9. Cheadle C, Fan J, Cho-Chung YS, Werner T, Ray J, Do L, Gorospe M, Becker KG (2005). "Control of gene expression during T cell activation: alternate regulation of mRNA transcription and mRNA stability". BMC Genomics 6: 75.doi:10.1186/14712164-6-75. PMC 1156890. PMID 15907206. 
10. Jackson DA, Pombo A, Iborra F (2000). "The balance sheet for transcription: an analysis of nuclear RNA metabolism in mammalian cells". FASEB J. 14 (2): 24254. PMID 10657981.

11. Schwanekamp JA, Sartor MA, Karyala S, Halbleib D, Medvedovic M, Tomlinson CR (2006). "Genome-wide analyses show that nuclear and cytoplasmic RNA levels are differentially affected by dioxin". Biochim. Biophys. Acta 1759 (8-9): 388402. doi:10.1016/j.bbaexp.2006.07.005. PMID 16962184.

12. Maloy, S., and J. Roth. 1983. Regulation of proline utilization by Salmonella typhimurium: characterization of put::Mud(Ap,lac) operon fusions. J. Bacteriol. 154: 561-568.

13. Pessi, G., C. Blumer, and D. Haas. 2001. lacZ fusions report gene expression, don't they? Microbiology 147: 1993-1995.

14. Pessi, G., C. Blumer, and D. Haas. 2001. lacZ fusions report gene expression, don't they? Microbiology 147: 1993-1995.

15. Silhavy, T. 2000. Gene fusions. J. Bacteriol. 182: 5935-5938.

16. Silhavy, T., and J. Beckwith. 1985. Uses of lac fusions for the study of biological problems. Microbiol. Rev. 49: 398-418.

17. http://www.sci.sdsu.edu/ smaloy/MicrobialGenetics/topics/regulation/reglevel.html

18. http://www.tiem.utk.edu/ gross/bioed/webmodules/aminoacid.htm

19. Dyer, K. F. 1971. The quiet revolution: A new synthesis of biological knowledge. Journal of Biological Education 5:15-24.

20. King, J. L. and T. H. Jukes. 1969. Non-Darwinian evolution. Science 164:788-798

21. Eisenberg E1, Levanon EY. Human housekeeping genes, revisited. Trends Genet. 2013 Oct;29(10):569-74. doi: 10.1016/j.tig.2013.05.010. Epub 2013 Jun 27.

22. Keertan Dheda1, Jim F. Huggett1, Stephen A. Bustin2, Margaret A. Johnson1, Graham Rook1, and Alimuddin Zumla1 Validation of housekeeping genes for normalizing RNA expression in real-time PCR BioTechniques 37:112-119 (July 2004) 
23. Frederickson RM1, Sonenberg N. Signal transduction and regulation of translation initiation. Semin Cell Biol. 1992 Apr;3(2):107-15.

24. Dobrikov MI1, Dobrikova EY, Gromeier M. Dynamic regulation of the translation initiation helicase complex by mitogenic signal transduction to eukaryotic translation initiation factor 4G. Mol Cell Biol. 2013 Mar;33(5):937-46. doi: 10.1128/MCB.01441-12. Epub 2012 Dec 21. 